\title{
"The relationship between CEO compensation and financial performance in Jordanian public shareholding industrial companies"
}

\begin{tabular}{|c|c|}
\hline AUTHORS & Marie H. Bani Khaled iD https://orcid.org/0000-0002-4083-3088 \\
\hline ARTICLE INFO & $\begin{array}{l}\text { Marie H. Bani Khaled (2020). The relationship between CEO compensation and } \\
\text { financial performance in Jordanian public shareholding industrial companies. } \\
\text { Investment Management and Financial Innovations, 17(2), 240-254. } \\
\text { doi:10.21511/imfi.17(2).2020.19 }\end{array}$ \\
\hline DOI & http://dx.doi.org/10.21511/imfi.17(2).2020.19 \\
\hline RELEASED ON & Monday, 29 June 2020 \\
\hline RECEIVED ON & Thursday, 21 May 2020 \\
\hline \multirow[t]{2}{*}{ ACCEPTED ON } & Wednesday, 17 June 2020 \\
\hline & $(\mathrm{cc}) \overline{\mathrm{EY}}$ \\
\hline LICENSE & $\begin{array}{l}\text { This work is licensed under a Creative Commons Attribution } 4.0 \text { International } \\
\text { License }\end{array}$ \\
\hline JOURNAL & "Investment Management and Financial Innovations" \\
\hline ISSN PRINT & $1810-4967$ \\
\hline ISSN ONLINE & $1812-9358$ \\
\hline PUBLISHER & LLC “Consulting Publishing Company "Business Perspectives" \\
\hline FOUNDER & LLC “Consulting Publishing Company "Business Perspectives" \\
\hline
\end{tabular}

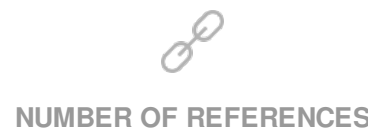

55
NUMBER OF FIGURES

0

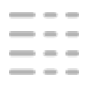

NUMBER OF TABLES

7

(C) The author(s) 2023. This publication is an open access article. 


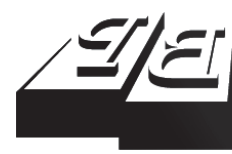

\section{BUSINESS PERSPECTIVES}

LLC "CPC "Business Perspectives" Hryhorii Skovoroda lane, 10, Sumy, 40022, Ukraine www.businessperspectives.org
Received on: $21^{\text {st }}$ of May, 2020 Accepted on: $17^{\text {th }}$ of June, 2020 Published on: $29^{\text {th }}$ of June, 2020
Marie H. Bani Khaled, Ph.D., Department of Business Administration, Faculty of Finance and Business Administration, $\mathrm{Al}$ al-Bayt University, Jordan.

\section{THE RELATIONSHIP BETWEEN CEO COMPENSATION AND FINANCIAL PERFORMANCE IN JORDANIAN PUBLIC SHAREHOLDING INDUSTRIAL COMPANIES}

\begin{abstract}
This study aimed to examine the relationship between the compensation received by chief executive officers (CEOs) and the financial performance of Jordanian public shareholding industrial companies listed on the Amman Stock Exchange (ASE) from 2010 to 2017. To measure the variables of interest, secondary data published on the ASE website were processed to become preliminary data suitable for the study. The study population consisted of 56 companies, 25 of which met the inclusion criteria. The results of the analysis of the data on these 25 companies revealed a large difference between the amount of financial compensation received by CEOs and the earnings per share (EPS) received by shareholders. The results also showed a statistically positive and significant relationship between the amount of CEO compensation and the financial performance of industrial companies. Furthermore, return on assets (ROA), EPS, and leverage have a statistically negative and significant relationship with financial performance. However, the net profit margin has a statistically positive and significant relationship with financial performance. Besides, the results showed a positive and significant relationship between the age of the $\mathrm{CEO}$ and the amount of compensation received. On the other hand, Tobin's Q model demonstrated that the relationship between CEO duality and the amount of CEO compensation is not statistically significant. Therefore, the study recommends using more than one type of compensation for the CEOs of public shareholding industrial companies in Jordan and that CEO compensation should be related to financial performance.
\end{abstract}

Keywords

CEO compensation, financial performance, financial ratios, Jordanian public shareholding industrial companies

\section{JEL Classification J33, G34, G35}

\section{INTRODUCTION}

The recruitment and appointment of a professional chief executive officer (CEO) or general manager is one of the main functions of the board of directors and is particularly important when one considers that the CEO is often also the chief operating officer and represents all of the employees of the organization before the board of directors and the shareholders. The CEO plays an important role in achieving the desired results in the long-term success of an organization. As a corollary, the board's effectiveness depends on the effectiveness of the CEO appointed by the board. Therefore, the board has a fundamental responsibility to appoint a suitable person for this position.

However, this responsibility does not end with the appointment of the $\mathrm{CEO}$; to retain them, the board is also required to decide on an appropriate amount of compensation. In any company, the compensation received by a CEO is very large compared to that paid to other em- 
ployees. For example, in the United States, the Center of Chief Executive Research conducted a survey of 1,631 companies in 2018; the results showed that the mean amount of CEO compensation was USD 2,152,733 (Chief Executive Research, 2019). This large salary gap between CEOs and other employees does not imply that the former have a higher level of academic qualifications; rather, the higher amount of financial compensation reflects the perception of their talent (skills and experience) and ability to steer an organization to success (Jung \& Subramanian, 2017).

Other reasons that might contribute to the amount of wages and incentives that a CEO receives include their power to determine their own wages, as well as success in achieving higher rates of productivity, increasing the rate of profitability, and increasing the market value of company stocks during their tenure (Mishra, McConaughy, \& Gobeli, 2000). Besides, there are other contributory factors in the case of family-owned and family-run businesses (Michiels, Voordeckers, Lybaert, \& Steijvers, 2013). It has also been argued that the high earnings of CEOs can be attributed to an increase in economic growth, an increase in the demand for a company's products, and a decrease in the intensity of competition through mergers among large companies to acquire market share (Guest, 2009). In support of this last factor, Bugeja, Da Silva Rosa, Duong, and Izan (2012) found that CEOs receive higher compensation in the year in which acquisition or mergers are completed and the following year.

In light of the above, this study is important because it attempts to find answers to the following key questions in the context of Jordan, an emerging economy:

1. What is the relationship between the compensation received by CEOs and the financial performance of Jordanian public shareholding industrial companies?

2. What is the relationship between the compensation received by CEOs and the characteristics of CEOs in Jordanian public shareholding industrial companies?

\section{LITERATURE REVIEW}

\subsection{CEO compensation}

In light of the acceleration in business growth throughout the world and the emergence of globalization, company owners prefer that competent professionals manage their organizations. Therefore, in the context of this study, the top management of a company, the CEO, can be considered a business agent who serves the company and is given the necessary level of authority and delegated powers to make the best decisions in the interest of the company. However, differences between the interests of CEOs and the owners may arise, which can lead to conflict, or the so-called agency problem, where CEOs may choose to place their personal goals above those of the company.

According to the allocation theory of control, in a major company, a professional CEO occupies the best position because their salary tends to increase as a result of any marginal increase in the produc- tivity of their company, thus providing a theoretical basis for the existence of a positive relationship between CEO compensation and the size of the company (Lau \& Vos, 2004).

On the other hand, according to agency theory, CEOs' compensation should be positively related to the company's performance. However, this theory does not provide any guidance as to the strength of that correlation. Therefore, many studies have tried to measure this relationship. The most notable study is that Jensen and Murphy (1990) found that the compensation of the CEO in many industries seems somewhat insensitive to company performance; that is to say, there is a statistically significant positive correlation, but the value of the coefficient is small.

In the current study, CEO compensation is measured using the natural logarithm ( $\mathrm{Ln})$ to ascertain the total amount of compensation received by the CEOs in the study sample, namely, Jordanian public shareholding industrial companies. This 
variable was adopted following previous studies (Banker, Darrough, Huang, \& Plehn-Dujowich, 2013; Kanapathippillai, Gul, Mihret, \& Muttakin, 2019; Nourayi \& Daroca, 2008; Parthasarathy, Menon, \& Bhattacherjee, 2006; Perry \& Zenner, 2001).

\subsection{Financial performance scales}

Generally speaking, companies produce financial statements that contain preliminary financial results that are of limited informational value. Therefore, financial ratios are very useful tools for measuring and evaluating the business performance that is described in these financial statements. These ratios can be used to understand profitability, asset management, liquidity, and key business trends, as well as assess management performance and overall effectiveness (Alexander, 2018). In short, financial ratios play a crucial role in the analysis of financial statements because these statements provide the proper basis for evaluating the financial status of a business entity (Knight \& Bertoneche, 2000). The most useful of these ratios are return on assets (ROA), Tobin's Q model, earnings per share (EPS), net profit margin (NPM), and leverage.

\subsubsection{Return on assets}

Investors and managers are often more interested in the amount of profit derived from invested capital than the profit level as a percentage of sales. Companies that operate in industries that need large capital often have high-profit margins, but these companies are often less attractive when the amount of invested or exploited capital is taken into account (Knight \& Bertoneche, 2000; Kato \& Kubo, 2006; Lilling, 2006; Mitsudome, Weintrop, \& Hwang, 2008). The following formula can represent the ROA ratio:

$$
\text { Return on assets }=\frac{\text { EBIAT }}{\text { Total assets }},
$$

where EBIAT denotes earnings before interest after taxes.

\subsubsection{Tobin's $Q$ model}

Also known as the $\mathrm{R}$ ratio, Tobin's $\mathrm{Q}$ is one of the most important measures used in representing the companies' performance. It reflects the po- tential growth of the company's assets, which is calculated by dividing the total market value of the company by the total value of the company's assets. The Tobin's Q indicates whether the company's assets' market value is estimated at a value higher or lower than the book value of the company's assets. This variable has been used in several previous studies (e.g., Alabede \& Muff, 2015; Cui \& Mak, 2002; Dezső \& Ross, 2008; Weber \& Dudney, 2003; Chung \& Pruitt, 1994). The following formula can represent the $\mathrm{R}$ ratio:

$$
\text { Tobin's } Q=\frac{\text { Market value of firm }}{\text { Assets value of firm }} \text {. }
$$

\subsubsection{Earnings per share}

The EPS can be described as a general scale of efficiency reflecting how much a regular shareholder will earn after deducting the premium share of the net profit after interest and taxes. A firm's management tends to use EPS as an indicator and a standard against which many decisions are measured, particularly those related to the financing of future company expansion (Gitman, Juchau, \& Flanagan, 2015). This variable has been used in prior work (e.g., van der Laan, Van Ees, \& Van Witteloostuijn, 2010). The following formula can represent the EPS ratio:

Earnings available

$$
\text { Earning per share }=\frac{\text { for common stockholders }}{\text { Number of shares }} .
$$

\subsubsection{Net profit margin}

The NPM is used to measure the percentage value of sales revenue after deducting all costs and expenses, including interest, taxes, and preferred stock distributions. The higher the company's NPM, the better. The NPM is considered a general scale that can be used to determine the efficiency of management, as reflected in the company's production, selling, and financing activities (Gitman et al., 2015; Nulla, 2013). The following formula can represent the NPM ratio:

\section{Earnings available}

$$
\text { Net profit margin }=\frac{\text { for common stockholders }}{\text { Sales }} \text {. }
$$




\subsubsection{Leverage}

Essentially, leverage is a ratio used to measure the company's reliance on third-party funds to finance its assets. When the percentage of leverage rises, the financing and non-payment risks also rise. Conversely, the lower the percentage of leverage, the stronger the indication that the company's owners have invested additional funds in the company (Brigham \& Houston, 2019; Elsayed \& Elbardan, 2018; Hall \& Liedtka, 2005), which thus implies enhanced confidence and stability. The following formula can represent the leverage ratio:

$$
\text { Leverage }=\frac{\text { Total dept }}{\text { Total dept }+ \text { Equity }} .
$$

\subsubsection{Company size}

Last but not least, company size is an important indicator of performance. As in the current study, company size can be measured using the Ln for the company's total assets. Companies with a large capital can diversify their sources of income, making them competitive and thus less vulnerable to bankruptcy. Furthermore, such companies are less likely to borrow, and this consequently reduces the cost of financing (Allen \& McAllister, 2018; Blackwell, Dudney, \& Farrell, 2007; Chen, 2005).

\subsection{CEO characteristics}

\subsubsection{CEO duality}

In the current study, CEO duality is used as a dummy variable. In other words, $\mathrm{CEO}$ duality is represented by giving a value of 1 to the CEO variable if the $\mathrm{CEO}$ is also a member of the board of directors, otherwise 0 . This approach is in line with previous research (Fahlenbrach, 2009; Feng, Ghosh, \& Sirmans, 2007; Saravanan, Srikanth, \& Avabruth, 2016; Sheikh et al., 2018).

\subsubsection{CEO age}

Many studies have shown that the age of the CEO has a positive correlation with company performance (Serfling, 2014), which is reflected in the amount of the CEO compensation awarded (Nulla, 2013; Zhang \& LV, 2017). However, Bhabra and Zhang Yu. (2016) found a negative correlation between the age of the CEO and the growth and market value of the company, and that the sensitivity of this relation decreases according to company profitability; Bhabra and Zhang Yu (2016) also found that there is a positive relationship between company profitability and young CEOs in the case of small companies, and a negative relationship between profitability and older CEOs in the case of large companies, which implies that the relationship between CEO age and company performance may be more nuanced.

\subsection{Compensation of CEOs and financial performance}

Financial performance is a key indicator for companies because it underpins continuity and sustainability. This indicator's importance has increased in recent years, as indicated by the literature in this area that has sought to determine the factors that are most important to improving financial performance and, thus, the achievement of company objectives. Moreover, the literature has shown a positive correlation between the value of CEO compensation and financial performance. Hence, financial performance is also associated with CEO characteristics.

Brick, Palmon, and Wald (2006) indicated that one of the most important reasons for the existence of a positive correlation between the amount of CEO compensation and a company's financial performance is the performance of the CEO because the talents and efforts of the CEO are reflected in the financial performance of the company. However, Gregg, Machin, and Szymanski (1993) found that the amount of CEO compensation is only weakly associated with financial performance. Moreover, Jenson and Meckling (1976) indicated that not all the activities performed by a CEO, whether paid or compensation-based, are necessarily in favor of the company, given that a CEO has privileged information about the company, and they are responsible for controlling all its activities. Nevertheless, a company's financial performance can be defined as a measure of whether the company's objectives have been achieved efficiently and effectively (Wachira, 2012). Company performance can also be defined as the ability to maintain growth and income stability. Accordingly, the following hypotheses were formulated for the current study: 
H1: There is a statistically significant relationship at sig. $\alpha \leq 0.05$ between the compensation of CEOs and the financial performance of Jordanian public shareholding industrial companies.

H1-a: There is a statistically significant relationship at sig. $\alpha \leq 0.05$ between the amount of financial compensation received by CEOs and the return on assets of the company.

H1-b: There is a statistically significant relationship at sig. $\alpha \leq 0.05$ between the amount of financial compensation received by CEOs and the earnings per share of the company.

H1-c: There is a statistically significant relationship at sig. $\alpha \leq 0.05$ between the amount of financial compensation received by $C E O s$ and the market value of the company.

H1-d: There is a statistically significant relationship at sig. $\alpha \leq 0.05$ between the amount of financial compensation received by CEOs and the company's net profit margin.

H2: There is a statistically significant relationship at sig. $\alpha \leq 0.05$ between the financial compensation received by the $C E O$ and the characteristics of the CEO in Jordanian public shareholding industrial companies.

H2-a: There is a statistically significant relationship at sig. $\alpha \leq 0.05$ between the amount of financial compensation received by the CEO and CEO duality.

H2-b: There is a statistically significant relationship at sig. $\alpha \leq 0.05$ between the amount of financial compensation received by the CEO and the age of the CEO.

\subsection{Previous studies}

Elsayed and Elbardan (2018) aimed to determine whether the compensation received by CEOs had a significant impact on the performance of companies or vice versa by analyzing the data of FTSE 350 companies, i.e., the largest 350 companies listed on the London Stock Exchange, from 2010 to 2014 . The study concluded that there is a positive and important relationship between the compensation of CEOs and the performance of these companies, which is in line with agency theory.

Xia and Meng-Lei (2017) looked at the structure of the financial compensation offered to CEOs of non-financial U.S. companies and the impact that CEOs have on company performance. The study was conducted on a sample of 828 companies based in the United States, and it concluded that the level of compensation as a whole has a positive impact on financial performance, according to Tobin's Q model and the ROA scale. It also concluded that equity-based compensation acts as a positive incentive that pushes CEOs to improve their performance. However, it should be noted that restricted stocks represented equity-based compensation because it has been argued that stock options have no impact on corporate performance. Hence, the result reported by Xia and Meng-Lei (2017) differs from those reported in most previous studies. Moreover, the study also stated that while salary accounted for only $27.6 \%$ of the total compensation package received by CEOs in the sample, it seems to have been awarded by using methods that have a negative impact on company performance.

Choi and Kim (2017) attempted to ascertain whether equity-based compensation impacted the market's ability to predict future returns by investigating the data on a sample of 1,500 companies listed on the S\&P 1500 from 1995 to 2007. The study concluded that equity-based compensation enhances the relationship between current and future returns. This indicates that an increase in information about future earnings is reflected in current stock prices.

Meanwhile, Fallatah (2015) indicated a significant relationship between CEO compensation and performance measures in Saudi Arabian companies. The study also found that using the compensation contract to align the actions of the CEOs with the success of the company through the idea of "pay for performance" is the strategy used by most companies in the sample.

In a larger study covering several countries, Yang, Dolar, and Mo (2014) explored the impact 
of CEO compensation on performance before and after the global financial crisis of 20072008 by studying the data on 3,286 different companies and 6,224 CEOs. The study concluded that the relationship between CEO compensation and company performance exhibits different patterns in the periods before and after the global financial crisis. The incentive-based contracts that were given to CEOs did not constitute an effective tool in improving the financial results of companies in the wake of the crisis. The study also found a positive, statistically significant impact on CEO compensation on performance before and after the crisis.

On the other hand, Conyon and He (2012) examined CEOs' compensation in Chinese companies by focusing on three main questions: (i) Are CEOs compensated based on company performance? (ii) Is CEO compensation important to the company? and (iii) Does corporate governance affect CEO compensation? The study relied on data on the compensation of the CEOs of the Chinese companies listed on the Chinese Stock Exchange from 2000 to 2010. The study concluded that CEO compensation is positively related to accounting performance, as represented by ROA and the market performance of the companies' stock in the study sample. The study also found that $\mathrm{CEO}$ equity and stock granting are affected by the structure of the board of directors and the structure of equity.

In a different vein, Bugeja et al. (2012) looked at the compensation received by the CEOs of 177 Australian companies that underwent a merger and/or acquisition from 2000 to 2007. The study found that CEOs receive higher compensation in the year in which the acquisition/merger is completed, as well as in the following year. The study also concluded that there is a positive correlation between CEO compensation and company performance, as well as between some of the measures of CEO effort and skill in completing the merger/acquisition transaction. Nevertheless, it was also revealed that CEOs receive less reward and compensation if they have more administrative authority (i.e. if the CEO is a member of the board of directors or a member of a board committee such as the nominations committee).
Also, in the Australian context, Matolcsy and Wright (2011) estimated a model of the CEO compensation structure in order to try to identify an "efficient structure" based on company characteristics and to develop a test to assess the performance outcomes that would result from a deviation from the effective CEO compensation structure. To achieve these objectives, the study examined 3,503 firm years covering the period 1999-2005. The study concluded that a company whose CEO receives compensation that is inconsistent with the company's performance shows poorer performance than a company whose CEO compensation level is consistent with the company's characteristics.

Finally, Elsaid, Davidson, and Wang (2011) compared the negotiating power of internally and externally appointed CEOs. To achieve this objective, the results of 99 CEOs appointed from outside the company were compared with those of 99 CEOs appointed from within the company for the period 1992-2003. The study found that a CEO from outside the company has greater bargaining power than a CEO from within the company, and therefore the CEO from outside the company enjoys greater compensation than a CEO from within the company. Besides, the study found that the appointment of a CEO from abroad poses a greater risk than the CEO appointed from within the company because of information asymmetry when hiring an outsider.

\section{METHODOLOGY}

\subsection{Study population and sample}

In the current study, the financial data of all 25 Jordanian public shareholding industrial companies listed on the ASE is included in the analysis. The data covered eight years from 2010 to 2017 and were downloaded from the ASE website. The period 2010-2017 was chosen to avoid the impact of the global financial crisis and was also based on the availability of relevant information on these companies. The data were in the form of a balanced panel dataset consisting of 200 observations. Table 1 shows the companies' distribution in the study sample according to the nature of their industrial activity. 
Table 1. Distribution of companies by industry

\begin{tabular}{l|c}
\multicolumn{1}{c}{ Activity } & No. of companies \\
\hline Chemical & 6 \\
\hline Electrical & 2 \\
\hline Engineering & 5 \\
\hline Food & 5 \\
\hline Mining & 4 \\
\hline Pharmaceutical & 2 \\
\hline Textile & 1 \\
\hline Total & 25 \\
\hline
\end{tabular}

\subsection{Study models}

To achieve the study objectives, a multiple linear regression model was used as represented by the following formulas:

$$
\begin{aligned}
& \text { Ln }(\text { Compensation })_{i t}=\alpha+\beta_{1} R O A_{i t}+ \\
& +\beta_{2}{\text { Tobin's } Q_{i t}+\beta_{3} E S_{i t}+\beta_{4} N P M_{i t}+}+ \\
& +\beta_{5} \text { Leverage }_{i t}+\beta_{6} \text { Ln }_{\text {Total assets }}+\varepsilon_{i t}, \\
& \text { Ln }(\text { Compensation })_{i t}=\alpha+\beta_{1} \text { CEO Duality } \\
& +\beta_{2} \text { CEO Age } \\
& i t
\end{aligned}
$$

where Ln(Compensation) - Logarithm for compensation, ROA - Return on assets, Tobin's $Q$ - Tobin's Q model, EPS - Earnings per share. $N P M$ - Net profit margin, Leverage - Financial leverage, Ln(Total assets) - Logarithm for total assets, CEO Duality - The duality of the CEO, CEO Age - The age of the CEO.

\subsection{Data analysis and hypotheses testing}

\subsubsection{Descriptive statistics}

Table 2 provides the summary statistics for the study variables, as reported previously. The monetary value is given in Jordanian dinar (JOD).
Referring to Table 2, the analysis of the data revealed the following key points:

- CEO compensation: The mean amount of CEO compensation was JOD 107,971, with a standard deviation of JOD 73,130. The compensation ranged from JOD 8,272 to JOD 338,165. This reveals that there is a significant disparity in the amount of compensation received by CEOs in Jordanian public shareholding industrial companies. This discrepancy may be attributed to the companies' performance that is correlated to the amount of compensation.

- Return on assets: The mean ROA was 3.2\%, with a standard deviation of approx. 7.1\%. The mean ranged from $-28.3 \%$ and $38.4 \%$. This indicates that there is a significant disparity in the ROA of Jordanian public shareholding industrial companies. This disparity may be due to the type of industrial activity engaged in by the companies in addition to their performance.

Tobin's $Q$ model: The mean of Tobin's Q model was $69.4 \%$, with a standard deviation of approx. $56.5 \%$. The mean ranged from a min. of approx. $2.9 \%$ to a max. of approx. $359.5 \%$. This indicates that some companies have a very high market value because of their high performance. However, there are also some companies that have a very low market value compared to the value of the underlying investment.

- Earnings per share: The mean EPS was $18.0 \%$, with a standard deviation of $49.4 \%$. The mean

\begin{tabular}{|c|c|c|c|c|c|}
\hline Variable & Mean & Median & Maximum & Minimum & Std. Dev. \\
\hline Compensation & JOD 107,971 & JOD 84,386 & JOD 338,165 & JOD 8,272 & JOD 73,130 \\
\hline ROA & $3.2 \%$ & $2.8 \%$ & $38.4 \%$ & $-28.3 \%$ & $7.1 \%$ \\
\hline Tobin's Q & $69.4 \%$ & $52.6 \%$ & $359.5 \%$ & $2.9 \%$ & $56.5 \%$ \\
\hline EPS & $18.0 \%$ & $6.7 \%$ & $359.7 \%$ & $-107.7 \%$ & $49.4 \%$ \\
\hline NPM & $4.7 \%$ & $3.8 \%$ & $65.1 \%$ & $-64.7 \%$ & $16.9 \%$ \\
\hline Leverage & $30.9 \%$ & $27.8 \%$ & $94.5 \%$ & $2.5 \%$ & $20.2 \%$ \\
\hline Total assets & JOD $161,000,000$ & JOD 19,037,049 & JOD $1,800,000,000$ & JOD $3,658,872$ & JOD $377,000,000$ \\
\hline Age & 57 & 57 & 81 & 36 & 9 \\
\hline CEO Duality (Dummy Variable) & $64.5 \%$ & 1 & 1 & 0 & $48.0 \%$ \\
\hline
\end{tabular}
ranged from a min. of approx. $-107.7 \%$ to a max. of approx. $359.7 \%$. This shows that there is a significant disparity in the EPS among

Table 2. Summary statistics of the variables 
the Jordanian public shareholding industrial companies.

- Net profit margin: The mean of the NPM was $4.7 \%$, with a standard deviation of $16.9 \%$. The mean ranged from a min. of approx. $-64.7 \%$ to a max. of approx. $65.1 \%$.

- Leverage: The mean leverage rate was $30.9 \%$, with a standard deviation of approx. 20.2\%. The rate ranged from a min. of approx. 2.5\% to a max. of approx. $94.5 \%$. This indicates that companies rely on equity to finance their assets.

- Total assets: The mean of the total assets was JOD 161,000,00, with a standard deviation of approx. JOD 377,000,000. The rate ranged from a min. of approx. JOD3,658,872 to a max. of approx. JOD 1,800,000.

- $\quad C E O$ age: The mean age of the CEOs was 57 years, which indicates that most CEOs have very long working experience.

\subsubsection{Multicollinearity test}

A correlation coefficient of up to $70 \%$ is considered to indicate multiple linear correlation problems. Thus, a high Pearson's correlation coefficient indicates a strong and almost complete relationship among the variables. When this occurs, it makes the values of the coefficient of interpretation unreal (Sekaran \& Bougie, 2016). Table 3 shows the relationships between the independent variables according to Pearson's correlation coefficient value.

Referring to Table 3, all the correlation coefficient values were less than 0.70 . Therefore, it was concluded that there was no problem with multiple linear correlations among the study variables, and there were no complete linear relationships among the independent variables of the study. Besides, further collinearity test was performed to determine whether linear duality was present among the variables used in the analysis. Table 4 shows the results of this test.

Table 4. Tolerance and Variance Inflation Factor (VIF) test

\begin{tabular}{l|c:c}
\hline \multirow{2}{*}{ Model } & \multicolumn{2}{c}{ Collinearity statistics } \\
\cline { 2 - 3 } & Tolerance & VIF \\
\hline ROA & .315 & 3.172 \\
\hline Tobin's Q & .436 & 2.295 \\
\hline EPS & .340 & 2.938 \\
\hline NPM & .468 & 2.135 \\
\hline Leverage & .728 & 1.374 \\
\hline Ln(Total Assets) & .581 & 1.721 \\
\hline
\end{tabular}

Referring to Table 4, the test results revealed that there was no linear duality among the variables because the variation inflation factor for each of the independent variables was less than 10 (ranging between 1.374 and 3.172). Furthermore, the value of the variance that was allowed for all the variables was greater than 0.05 (ranging between 0.340 and 0.728 ). Therefore, it was concluded that the correlation among the variables was not high, indicating a lack of linear duality among the variables (Miles, 2014).

\subsubsection{Hausman test results}

After confirming that linear duality and homogeneity were not present, the data were subjected to a regression analysis using the ordinary least squares method. Besides, the fixed effect model was used for the Hausman test value. Table 5 provides the results of the Hausman test.

Table 5. Correlated random effects - Hausman test

\begin{tabular}{c|c|c|c}
\hline Test summary & $\begin{array}{c}\text { Chi-sq. } \\
\text { statistic }\end{array}$ & $\begin{array}{c}\text { Chi-sq. } \\
\text { d.f. }\end{array}$ & Prob. \\
\hline Random cross-section & 30.660734 & 6 & 0.0000 \\
\hline
\end{tabular}

Table 3. Pearson's correlation coefficient values for the relationships between the variables

\begin{tabular}{|c|c|c|c|c|c|c|}
\hline & ROA & Tobin's Q & EPS & PMR & Leverage & Ln(Total Assets) \\
\hline ROA & 1 & 0.66069 & 0.65679 & 0.69726 & -0.26459 & 0.18961 \\
\hline Tobin's Q & 0.66069 & 1 & 0.64174 & 0.48533 & -0.36506 & 0.18681 \\
\hline EPS & 0.65679 & 0.64174 & 1 & 0.47611 & -0.10446 & 0.52434 \\
\hline NPM & 0.69726 & 0.48533 & 0.47611 & 1 & -0.29404 & 0.25598 \\
\hline Leverage & -0.26459 & -0.36506 & -0.10446 & -0.29404 & 1 & 0.23570 \\
\hline Ln(Total Assets) & 0.18961 & 0.18681 & 0.52434 & 0.25598 & 0.23570 & 1 \\
\hline
\end{tabular}




\section{RESULTS}

The first main hypothesis (H1) states that there would be a positive relationship between the compensation of the CEO and the financial performance of Jordanian public shareholding industrial companies was tested by using the following general linear model:

$$
\begin{aligned}
& \operatorname{Ln}(\text { Compensation })_{i t}=\alpha+\beta_{1} R O A_{i t}+ \\
& +\beta_{2} \text { Tobin's } Q_{i t}+\beta_{3} \text { EPS }_{i t}+\beta_{4} N P M_{i t}+ \\
& +\beta_{5} \text { Leverage }_{i t}+\beta_{6} \text { Ln }(\text { Total assets })_{i t}+\varepsilon_{i t} \text {, }
\end{aligned}
$$

where financial performance was represented by the independent variables ROA, Tobin's $Q$ model, EPS, NPM, Leverage, and the Ln of the company's total assets as a control variable.

The model was estimated by using the panel least squares method. The estimation is shown in Table 6, in which the results of the regression are shown based on using the $L n$ for the amount of CEO compensation ( $\ln$ compensation) as the dependent variable.

Referring to Table 6, ROA, Tobin's Q, EPS, NPM, leverage, and company size (total assets) as the model had a statistically significant relationship with the compensation received by CEOs in Jordanian public shareholding industrial companies. The calculated value of $\mathrm{F}$ was 18.65652 at sig./ Prob. $=0.000$, where the probability value ( $p$-value) was less than $\alpha \leq 0.05$. Hence, this result confirmed the hypothesis that there would be a relationship between the amount of the compensation received by CEOs and the performance of Jordanian public shareholding industrial companies.

The regression equation in Table 6 also shows a high illustrative value, where the value of the selection coefficient $\left(R^{2}\right)$ and the adjusted selection coefficient (adjusted $R^{2}$ ) were $76.80 \%$ and $72.69 \%$, respectively, i.e., the independent variables (performance) had an impact on the dependent variable (the amount of CEO compensation) of $76.80 \%$.

Moreover, the regression coefficient values revealed the following relationships between the independent variables and CEO compensation:

1. Return on assets had a negative and significant relationship with the amount of CEO compensation, where the $t$-statistic was -2.094082

\begin{tabular}{|c|c|c|c|c|}
\hline \multicolumn{5}{|c|}{ Dependent Variable: Ln(Compensation) } \\
\hline \multicolumn{5}{|c|}{ Method: Panel Least Squares } \\
\hline \multicolumn{5}{|c|}{ Date: 01/26/20 Time: 03:09 } \\
\hline \multicolumn{5}{|l|}{ Sample: 2010-2017 } \\
\hline \multicolumn{5}{|l|}{ Periods included: 8} \\
\hline \multicolumn{5}{|c|}{ Cross-sections included: 25} \\
\hline \multicolumn{5}{|c|}{ Total panel (balanced) observations: 200} \\
\hline Variable & Coefficient & Std. Error & t-statistic & Prob. \\
\hline ROA & -0.856944 & 0.409222 & -2.094082 & 0.0377 \\
\hline Tobin's Q & 0.007694 & 0.044937 & 0.171220 & 0.8643 \\
\hline EPS & -0.097300 & 0.046731 & -2.082134 & 0.0388 \\
\hline NPM & 1.066826 & 0.189041 & 5.643373 & 0.0000 \\
\hline LEVERAGE & -0.632454 & 0.174594 & -3.622424 & 0.0004 \\
\hline Ln(Total Assets) & 0.345363 & 0.132149 & 2.613427 & 0.0098 \\
\hline C & 2.527904 & 0.971638 & 2.601692 & 0.0101 \\
\hline \multicolumn{5}{|c|}{ Effects specification } \\
\hline \multicolumn{5}{|c|}{ Cross-section fixed (dummy variables) } \\
\hline$R$-squared & 0.768079 & \multicolumn{2}{|c|}{ Mean dependent var } & 4.934858 \\
\hline Adjusted $R$-squared & 0.726909 & \multicolumn{2}{|c|}{ S.D. dependent var } & 0.305555 \\
\hline S.E. of regression & 0.159677 & \multicolumn{2}{|c|}{ Akaike info criterion } & -0.689745 \\
\hline Sum squared resid & 4.308956 & \multicolumn{2}{|c|}{ Schwarz criterion } & -0.178506 \\
\hline Log likelihood & 99.97447 & \multicolumn{2}{|c|}{ Hannan-Quinn criterion } & -0.482854 \\
\hline F-statistic & 18.65652 & \multicolumn{2}{|c|}{ Durbin-Watson stat } & 1.750328 \\
\hline Prob (F-statistic) & 0.000000 & & & \\
\hline
\end{tabular}
at sig./Prob. $=0.0377$, which was below the sta-

Table 6. Results of the regression equation (first model) 
tistical significance level of 0.05 . This means that ROA negatively affects the compensation received by the CEOs in the public shareholding industrial companies in Jordan.

2. Tobin's $Q$ had a positive but not statistically significant relationship with the amount of CEO compensation, where the calculated $t$-statistic was 0.171220 at sig./Prob. $=0.8643$, which was greater than the significance level of 0.05 . This means that there is a positive but insignificant relationship between Tobin's Q model and the compensation received by the CEOs.

3. Earnings per share had a statistically significant negative relationship with the amount of CEO compensation, where the value of the calculated $t$-statistic was -2.082134 at sig./Prob. $=$ 0.0388 , which was below the statistical level of significance of 0.05 . This means that there is a negative and significant relationship between EPS and the compensation of the CEOs.

4. Net profit margin had a statistically positive relationship with the amount of CEO compensation, where the calculated value of the $t$-statistic was
5.643 at sig./Prob. $=0.0000$, which was below the $p$-value of 0.05 . This means that there is a positive, significant relationship between NPM and the amount of CEO compensation.

5. Leverage had a statistically negative relationship with the amount of CEO compensation, where the calculated value of the $t$-statistic was -3.622424 at Prob. $=0.0004$, which was below the significance level set at $p=0.05$. This confirms that there is a negative and significant relationship between leverage and CEO compensation.

The second main hypothesis $(\mathrm{H} 2)$ states that there would be positive effects of the age of the CEO and the duality of the CEO on CEO compensation in Jordanian public shareholding industrial companies was tested by using the following general linear model:

$$
\begin{aligned}
& \text { Ln }(\text { Compensation })_{i t}=\alpha+ \\
& +\beta_{1} \text { CEO Duality }{ }_{i t}+\beta_{2} \text { CEO Age } \text { A }_{i t}+\varepsilon_{i t} .
\end{aligned}
$$

This model was estimated using the panel least squares method. Table 7 shows the results of the

Table 7. Results of the regression equation (second model)

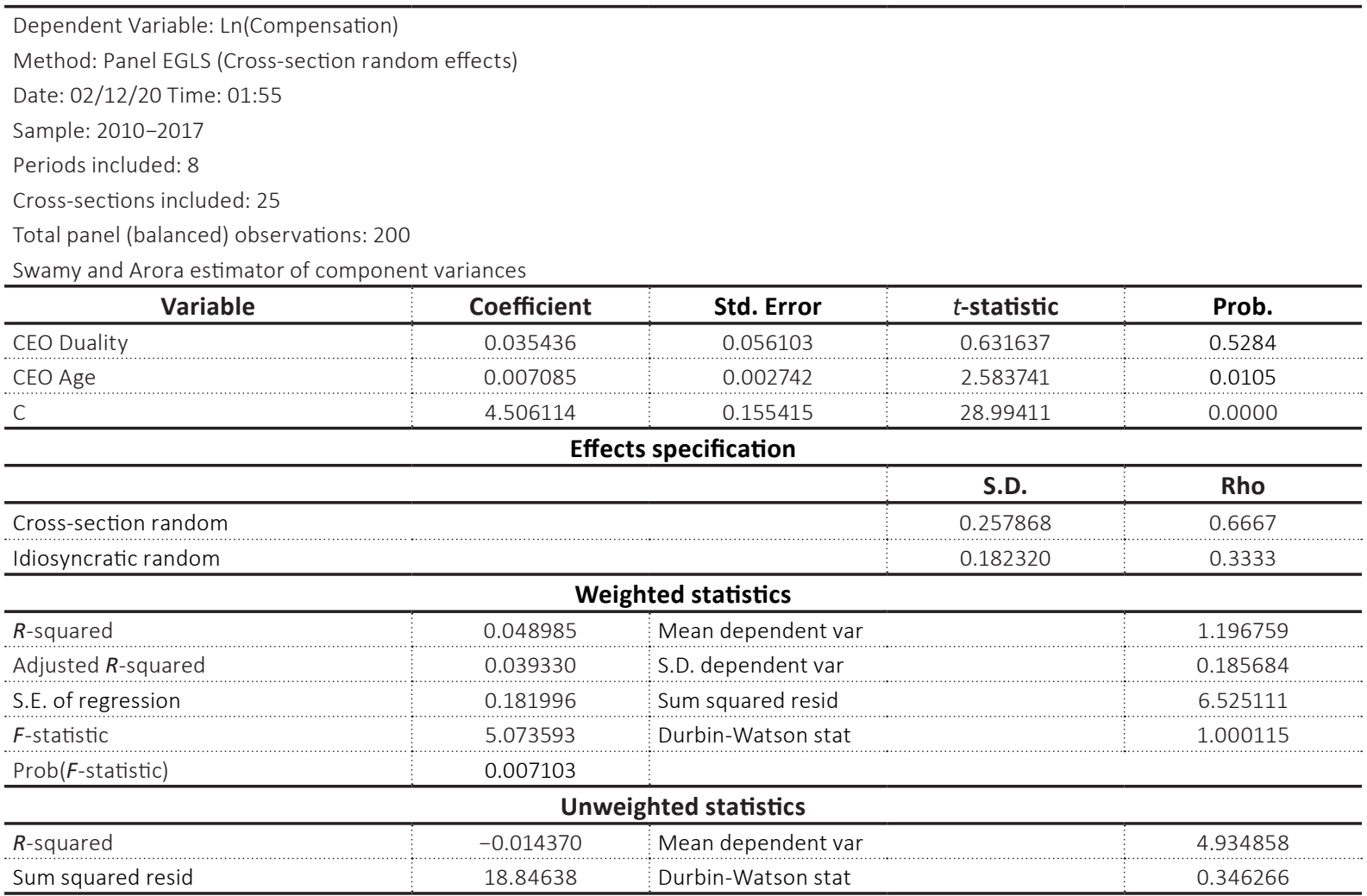


regression obtained using the Ln for the amount of CEO compensation (Ln Compensation) as the dependent variable. The results in Table 7 were obtained using EViews.

Referring to Table 7, CEO duality and CEO age as models had a statistically significant relationship with the amount of compensation received by the CEOs. The calculated value of $F$ was 5.073593, with a significance of Prob. $=0.007103$. Hence the $p$-value was less than $\alpha \leq 0.05$. Therefore, hypothesis $H 2$ was supported.

The regression equation in Table 7 shows an illustrative value for the selection coefficient $\left(R^{2}\right)$ and the adjusted selection coefficient (adjusted $R^{2}$ ), which were $4.89 \%$ and $3.93 \%$, respectively. This means that the independent variables (CEO duality and CEO age) as a model affect the dependent variable (amount of CEO compensation) by 3.93\%.

The regression coefficients' values showed that the independent variable CEO duality had a positive but insignificant relationship with CEO compensation, where the value of the $t$-statistic was 0.631637 at Prob. $=0.5284$, which was greater than the level of statistical significance (0.05). This means that CEO duality does not affect the amount of compensation received by CEOs.

On the other hand, CEO age had a positive and statistically significant relationship with CEO compensation, where the value of the $t$-statistic was 2.583741 at Prob. $=0.0105$, which was below the statistical level of significance (0.05). This means that there is a statistically positive relationship between $\mathrm{CEO}$ age and the amount of CEO compensation.

\section{DISCUSSION}

There is a large disparity in the amount of compensation received by the CEOs in Jordanian public shareholding industrial companies.

The compensation of CEOs has a statistically significant impact on the financial performance of Jordanian public shareholding industrial companies. This result is consistent with Conyon and He (2012), Elsayed and Elbardan (2018), Fallatah (2015), and Xia and Meng-Lei (2017).
Return on assets has a negative impact on the amount of compensation received by the CEOs in Jordanian public shareholding industrial companies. This means that the larger the amount of CEO compensation, the greater the effect on ROA because such compensation reduces net profit and thus negatively affects ROA. This result is consistent with Lilling (2006) and Xia and Meng-Lei (2017).

The amount of CEO compensation has a negative impact on EPS. This result can be explained if CEOs' compensation reflects the ROA of Jordanian public shareholding industrial companies. This result is consistent with van der Laan et al. (2010).

Net profit margin has a positive impact on the financial performance of Jordanian public shareholding industrial companies. This could be attributed to the fact that the top management in these companies, including the CEO, plays an important role in enhancing sales volume, and therefore this is reflected in the amount of CEO compensation. This result is consistent with Nulla (2013).

There is a statistically negative relationship between leverage and the amount of CEO compensation. In other words, the higher the company's indebtedness, the lower the amount of CEO compensation. This result is consistent with Bebchuk and Spamann (2009) and Elsayed and Elbardan (2018).

The size of the company plays a key role in determining the amount of compensation received by the CEOs in Jordanian public shareholding industrial companies. This is consistent with Allen and McAllister (2018), Blackwell et al. (2007), and Chen (2005).

The mean age of the CEOs was 57 years, which implies that most of the CEOs had a high level of working experience and which, in turn, suggests that this wealth of expertise would be reflected in the financial performance of the companies they managed as well as in the compensation received. This result is consistent with Nulla (2013), Serfling (2014), and Zhang and LV (2017).

Tobin's Q model had a positive but statistically insignificant relationship with the amount of compensation given to CEOs in Jordanian public shareholding industrial companies. 
CEO duality has a positive but statistically insignificant relationship with the compensation received by CEOs in Jordanian public shareholding industrial companies. This may be because most CEOs hold executive positions in these companies (i.e., the CEOs are also members of the board of directors). This result is consistent with Elsaid et al. (2011) and implies that governance in these companies is to be strengthened.

\section{CONCLUSION}

Based on the results obtained regarding the relationship between the amount of compensation received by CEOs and the financial performance of Jordanian public shareholding industrial companies, the following five key recommendations are made concerning enhancing the performance of these companies:

1. Motivate CEOs by giving them equity tools as a mechanism by which to relate their own performance to the financial performance of the company in which they hold a position.

2. Work on attracting highly qualified CEOs from outside the company to strengthen governance within the company.

3. Retain CEOs whose companies achieve high financial performance by awarding them appropriate compensation will enhance their productivity and, in turn, will be reflected in the company's improved performance.

4. Use leverage as a tool to relate the company's financial performance with the compensation received by the CEO to take advantage of the tax advantage.

5. Conduct further studies on the compensation of CEOs in companies to identify the determinants of and methods used in awarding compensation in the Jordanian context.

\section{AUTHOR CONTRIBUTIONS}

Formal analysis: Marie H. Bani Khaled.

Funding acquisition: Marie H. Bani Khaled.

Project administration: Marie H. Bani Khaled.

Resources: Marie H. Bani Khaled.

Writing - original draft: Marie H. Bani Khaled.

Writing - review \& editing: Marie H. Bani Khaled.

\section{REFERENCES}

1. Alabede, J. O., \& Muff, T.

(2015). Board Structures and

Financial Performance of UK

Top Firms: An Investigation

of the Moderating Role of the

Directors' Compensation. Issues

in Social and Environmental

Accounting, 1-17. Retrieved from

https://www.researchgate.net/

publication/301960140_Board_

Structures_and_Financial_Per-

formance_of_UK_Top_Firms_
An_Investigation_of_the_Moderating_Role_of_the_Directors'_ Compensation

2. Alexander, J. (2018). Financial planning \& analysis and performance management. John Wiley \& Sons.

3. Allen, A., \& McAllister, B. (2018). CEO compensation and performance in US private foundations. Financial
Accountability and Management, 34(2), 117-132. https://doi. org/10.1111/faam.12150

4. Banker, R. D., Darrough, M. N., Huang, R., \& Plehn-Dujowich, J. M. (2013). The relation between CEO compensation and past performance. Accounting Review, 88(1), 1-30. Retrieved from https://www.jstor.org/ stable/41721933?seq=1 
5. Bebchuk, L. A., \& Fried, J. M. (2003). Executive compensation as an agency problem. Journal of Economic Perspectives, 17(3), 71-92. Retrieved from http://www. law.harvard.edu/programs/corp_ gov/papers/2003.Bebchuk-Fried. Executive.Compensation.pdf

6. Bebchuk, L. A., \& Spamann, H. (2009). Regulating bankers' pay. Geo Law Journal, 98, 247-287. Retrieved from https://papers.ssrn. com/sol3/papers.cfm?abstract_ $\mathrm{id}=1410072$

7. Bhabra, H. S. \& Zhang Yu. (2016) CEO Age and Firm Performance. European Financial Management Association Conference.

8. Blackwell, D. W., Dudney, D. M., \& Farrell, K. A. (2007). Changes in CEO compensation structure and the impact on firm performance following CEO turnover. Review of Quantitative Finance and Accounting, 29(3), 315-338. Retrieved from https:// www.researchgate.net/publication/5157757_Changes_in_CEO_ compensation_structure_and the_impact_on_firm_performance_following_CEO_turnover

9. Brick, I. E., Palmon, O., \& Wald, J. K. (2006). CEO compensation, director compensation, and firm performance: Evidence of cronyism? Journal of Corporate Finance, 12(3), 403-423. https:// doi.org/10.1016/j.jcorpfin.2005.08.005

10. Brigham, E. F., \& Houston, J. F. (2019). Fundamentals of financial management. Cengage Learning.

11. Bugeja, M., Da Silva Rosa, R., Duong, L., \& Izan, H. Y. (2012). CEO Compensation from M\&As in Australia. Journal of Business Finance and Accounting, 39(9-10), 1298-1329. Retrieved from https:// www.researchgate.net/publication/256003027_CEO_Compensation_from_MAs_in_Australia

12. Chen, M. (2005). Group affiliation, identity of managers, and the relation between managerial ownership and performance. International Review of Financial Analysis, 14(5), 533-558. Retrieved from https://www.researchgate. net/publication/4950841_Group_ affiliation_identity_of_managers_and_the_relation_between_ managerial_ownership_and_performance

13. Chief Executive Research (2019). CEO and Senior Executive Compensation in Private Companies 2018-19. Retrieved from https://chiefexecutive. net/ceo-and-senior-executivecompensation-in-private-companies-2018-19/

14. Choi, B., \& Kim, J. B. (2017). The Effect of CEO Stock-Based Compensation on the Pricing of Future Earnings. European Accounting Review, 26(4), 651-679. https://doi.org/10.1080/09638180. 2016.1175364

15. Chung, K. H., \& Pruitt, S. W. (1994). A simple approximation of Tobin's Q. Financial Management, 23(3), 70-74. Retrieved from https://www.jstor.org/ stable $/ 3665623$ ? seq $=1$

16. Conyon, M. J., \& He, L. (2012). CEO Compensation and Corporate Governance in China. Corporate Governance: An International Review, 20(6), 575-592. https://doi.org/10.1111/ j.1467-8683.2012.00935.x

17. Cui, H., \& Mak, Y. T. (2002). The relationship between managerial ownership and firm performance in high R \& D firms. Journal of Corporate Finance, 8(4), 313-336. Retrieved from https://www.researchgate.net/ publication/222783617_The_Relationship_between_Managerial_Ownership_and_Firm_Performance_in_High_RD_firms

18. Dezső, C., \& Ross, D. (2008). "Girl Power": Female participation in top management and firm performance. Arbeitspapier, University of Maryland Und Columbia. Retrieved from https://www.researchgate.net/ publication/256009442_'Girl Power'_Female_Participation_in_ Top_Management_and_Firm_ Performance

19. Elsaid, E., Davidson, W. N., \& Wang, X. (2011). CEO successor compensation: Outside versus inside successions. Journal of Management and Governance,
15(2), 187-205. Retrieved from https://www.researchgate.net/publication/226018749_CEO_successor_compensation_Outside_versus inside_successions

20. Elsayed, N., \& Elbardan, H. (2018) Investigating the associations between executive compensation and firm performance: Agency theory or tournament theory. Journal of Applied Accounting Research, 19(2), 245-270. https:// doi.org/10.1108/JAAR-03-20150027

21. Fahlenbrach, R. (2009) Shareholder rights, boards, and CEO compensation. Review of Finance, 13(1), 81-113. Retrieved from https://papers.ssrn.com/sol3/ papers.cfm?abstract_id=390144.

22. Fallatah, Y. A., \& Fahd, K. (2015). CEO Compensation, Firm Performance and Corporate Governance: An Empirical Investigation of Saudi Arabian Companies.

23. Feng, Z., Ghosh, C., \& Sirmans, C. F. (2007). Director compensation and CEO bargaining power in REITs. Journal of Real Estate Finance and Economics, 35(3), 225-251. Retrieved from https:// link.springer.com/article/10.1007/ s11146-007-9043-9

24. Gitman, L. J., Juchau, R., \& Flanagan, J. (2015). Principles of managerial finance. Pearson Higher Education AU.

25. Gregg, P., Machin, S., \& Szymanski, S. (1993). The Disappearing Relationship between Directors' Pay and Corporate Performance. British Journal of Industrial Relations, 31(1), 1-9. https://doi. org/10.1111/j.1467-8543.1993. tb00377.x

26. Guest, P. M. (2009). The impact of mergers and acquisitions on executive pay in the United Kingdom. Economica, 76(301), 149-175. Retrieved from https://core.ac.uk/download/ pdf/138587.pdf

27. Hall, J. A., \& Liedtka, S. L. (2005). Financial performance, CEO compensation, and largescale information technology outsourcing decisions. Journal of 
Management Information Systems, 22(1), 193-221. https://doi.org/10.1 080/07421222.2003.11045838

28. Jensen, M. C., \& Murphy, K. J. (1990). Performance Pay and TopManagement Incentives. Journal of Political Economy, 98(2), 225-264. https://doi.org/10.1086/261677

29. Jensen, M. C., Murphy, K. J., \& Wruck, E. G. (2005). CEO pay and what to do about it. Speech SNS Stockholm.

30. Jenson, M. C., \& Meckling, W. H. (1976). Theory of the firm: managerial behavior, agency costs and ownership structure. Journal of Financial Economics, 3(4), 305-360. https://doi.org/10.1016/0304405X(76)90026-X

31. Jung, H. W. H., \& Subramanian, A. (2017). CEO talent, CEO compensation, and product market competition. Journal of Financial Economics, 125(1), 48-71. https://doi.org/10.1016/j. jfineco.2017.04.005

32. Kanapathippillai, S., Gul, F., Mihret, D., \& Muttakin, M. B. (2019). Compensation committees, CEO pay and firm performance. PacificBasin Finance Journal, 57, 101-187. Retrieved from https://ideas.repec. org/a/eee/pacfin/v57y2019ics0927538x18305754.html

33. Kato, T., \& Kubo, K. (2006). CEO compensation and firm performance in Japan: Evidence from new panel data on individual CEO pay. Journal of the Japanese and International Economies, 20(1), 1-19. https://doi.org/10.1016/j. jjie.2004.05.003

34. Knight, R., \& Bertoneche, M. (2000). Financial performance. Elsevier.

35. Lau, A., \& Vos, E. (2004). Relation between CEO compensation, firm size and firm performance. New Zealand Journal of Applied Business Research, 3(1), 51-64. Retrieved from https://www.semanticscholar. org/paper/Relation-between-CEOcompensation- $\% 2 \mathrm{C}$-firm-size-andLau-Vos/3e7035143510ccleff843f8 2f63ff0a21c404951

36. Lilling, M. S. (2006). The link between CEO compensation and firm performance: Does simultaneity matter? Atlantic Economic Journal, 34(1), 101114. Retrieved from https:// www.researchgate.net/ publication/5144187_The Link_Between_CEO_Compensation_and_Firm_Performance_Does_Simultaneity_Matter

37. Matolcsy, Z., \& Wright, A. (2011). CEO compensation structure and firm performance. Accounting \& Finance, 51(3), 745-763. Retrieved from https://www.researchgate. net/publication/227370555_CEO_ Compensation_Structure_and_ Firm_Performance

38. Michiels, A., Voordeckers, W., Lybaert, N., \& Steijvers, T. (2013). CEO compensation in private family firms: Pay-for-performance and the moderating role of ownership and management. Family Business Review, 26(2), 140-160. https://doi.org/ 10.1177\%2F0894486512454731

39. Miles, J. (2014). Tolerance and variance inflation factor. Wiley StatsRef: Statistics Reference Online.

40. Mishra, C. S., McConaughy, D. L., \& Gobeli, D. H. (2000). Effectiveness of CEO payfor-performance. Review of Financial Economics, 9(1), 1-13.区 https://doi.org/10.1016/S10583300(00)00015-X

41. Mitsudome, T., Weintrop, J., \& Hwang, L.-S. (2008). The relation between changes in CEO compensation and firm performance: A Japanese/ American comparison. Journal of the Japanese and International Economies, 22(4), 605-619. https:// doi.org/10.1016/j.jjie.2007.06.001

42. Nourayi, M. M., \& Daroca, F. P. (2008). CEO compensation, firm performance and operational characteristics. Managerial Finance, 34(8), 562-584. Retrieved from https://econpapers.repec.org/ article/ememfipps/v_3a34_3ay_3a 2008_3ai_3a8_3ap_3a562-584.htm

43. Nulla, Y. M. (2013). CEO Age and Top Executive Officer Compensation: An Empirical Study on Canadian Companies. SSRN Electronic Journal. https:// doi.org/10.2139/ssrn.2284344
44. Parthasarathy, A., Menon, K., \& Bhattacherjee, D. (2006).

Executive compensation, firm performance and governance: an empirical analysis. Economic and Political Weekly, 41(39), 41394147. Retrieved from https://www. jstor.org/stable/4418755?seq=1

45. Perry, T., \& Zenner, M. (2001). Pay for performance? Government regulation and the structure of compensation contracts. Journal of Financial Economics, 62(3), 453-488. https://doi.org/10.1016/ S0304-405X(01)00083-6

46. Saravanan, P., Srikanth, M., \& Avabruth, S. M. (2016). Executive compensation, corporate governance and firm performance: evidence from India. International Journal of Corporate Governance, 7(4), 377. Retrieve from https://www.researchgate. net/publication/313817695_Executive_compensation_corporate_governance_and_firm_performance_evidence_from_India

47. Sekaran, U., \& Bougie, R. (2016). Research methods for business: A skill building approach. John Wiley \& Sons.

48. Serfling, M. A. (2014). CEO age and the riskiness of corporate policies. Journal of Corporate Finance, 25, 251-273. https://doi. org/10.1016/j.jcorpfin.2013.12.013

49. Sheikh, M. F., Shah, S. Z. A., \& Akbar, S. (2018). Firm performance, corporate governance and executive compensation in Pakistan. Applied Economics, 50(18), 2012-2027. https://doi.org/10.1080/00036846. 2017.1386277

50. van der Laan, G., Van Ees, H., \& Van Witteloostuijn, A. (2010). Is pay related to performance in The Netherlands? An analysis of Dutch executive compensation, 2002-2006. De Economist, 158(2), 123-149. Retrieved from https:// link.springer.com/article/10.1007/ s10645-010-9140-7

51. Wachira, F. N. (2012). Relationship between Corporate Governance and Financial Performance of Microfinance Banks in Kenya. University of Nairobi. 
Retrieved from http://erepository.uonbi.ac.ke/bitstream/ handle/11295/99432/Wachira_Relationship\%20Between\%20Corporate $\% 20$ Governance $\% 20$ and $\% 20$ Financial\%20Performance $\% 20$ of $\% 20$ Microfinance $\% 20$ Banks $\% 20$ in\%20Kenya.pdf? sequence $=1$

52. Weber, M., \& Dudney, D. (2003). A reduced form coefficients analysis of executive ownership, corporate value, and executive compensation. Financial Review, 38(3), 399-413. https://doi. org/10.1111/1540-6288.00052
53. Xia, J., \& Meng-Lei, J. (2017). Firm Performance and Executive Compensation Structure. Paper presented at 3rd International Conference on Education and Social Development (pp. 817-823). Retrieved from http://dpi-proceedings.com/index.php/dtssehs/ article/view/11664

54. Yang, F., Dolar, B., \& Mo, L. (2014). CEO Compensation and Firm Performance: Did the 20072008 Financial Crisis Matter? Journal of Accounting and Finance, 14(1), 137-146. Retrieved from http://www.na-businesspress.com/ JAF/YangF_Web14_1_.pdf

55. Zhang, C., \& LV, Y. (2017). Effect of CEO Age on Executive Compensation Gap: Evidence from Chinese Listed Manufacturing Companies. In DEStech Transactions on Computer Science and Engineering, (ameit) (pp. 1-5). Retrieved from https://www.researchgate. net/publication/326791955_Effect_of_CEO_Age_on_Executive_ Compensation_Gap_Evidence_ from_Chinese_Listed_Manufacturing_Companies 